OPEN ACCESS

Edited by:

Dina M. Bower,

NASA Goddard Space Flight Center/University of Maryland, USA

Reviewed by:

Eric D. Van Hullebusch,

University Paris-Est, France Alan W. Decho,

University of South Carolina, USA

*Correspondence:

Anna A. Gorbushina anna.gorbushina@bam.de

Specialty section:

This article was submitted to Biogeoscience, a section of the journal Frontiers in Earth Science

Received: 03 August 2015 Accepted: 15 March 2016 Published: 21 April 2016

Citation:

Seiffert F, Bandow N, Kalbe U, Milke R and Gorbushina AA (2016) Laboratory Tools to Quantify Biogenic Dissolution of Rocks and Minerals: A Model Rock Biofilm Growing in Percolation

Columns. Front. Earth Sci. 4:31. doi: 10.3389/feart.2016.00031

\section{Laboratory Tools to Quantify Biogenic Dissolution of Rocks and Minerals: A Model Rock Biofilm Growing in Percolation Columns}

\author{
Franz Seiffert ${ }^{1}$, Nicole Bandow ${ }^{1}$, Ute Kalbe ${ }^{1}$, Ralf Milke ${ }^{2}$ and Anna A. Gorbushina ${ }^{1,2 *}$ \\ ' Department of Materials and Environment, Federal Institute for Materials Research and Testing, Berlin, Germany, \\ ${ }^{2}$ Department of Earth Sciences, Freie Universität Berlin, Berlin, Germany
}

Sub-aerial biofilms (SAB) are ubiquitous, self-sufficient microbial ecosystems found on mineral surfaces at all altitudes and latitudes. SABs, which are the principal causes of weathering on exposed terrestrial surfaces, are characterized by patchy growth dominated by associations of algae, cyanobacteria, fungi and heterotrophic bacteria. A recently developed in vitro system to study colonization of rocks exposed to air included two key SAB participants - the rock-inhabiting ascomycete Knufia petricola (CBS 123872) and the phototrophic cyanobacterium Nostoc punctiforme ATCC29133. Both partners are genetically tractable and we used them here to study weathering of granite, K-feldspar and plagioclase. Small fragments of the various rocks or minerals (1-6 mm) were packed into flow-through columns and incubated with $0.1 \%$ glucose and $10 \mu \mathrm{M}$ thiamine-hydrochloride $\left(90 \mu \mathrm{L} \mathrm{min}{ }^{-1}\right)$ to compare weathering with and without biofilms. Dissolution of the minerals was followed by: (i) analysing the degradation products in the effluent from the columns via Inductively Coupled Plasma Spectroscopy and (ii) by studying polished sections of the incubated mineral fragments/grains using scanning electron microscopy, transmission electron microscopy and energy dispersive X-ray analyses. K. petricola/N. punctiforme stimulated release of $\mathrm{Ca}, \mathrm{Na}, \mathrm{Mg}$ and $\mathrm{Mn}$. Analyses of the polished sections confirmed depletion of $\mathrm{Ca}$, $\mathrm{Na}$ and $\mathrm{K}$ near the surface of the fragments. The abrupt decrease in Ca concentration observed in peripheral areas of plagioclase fragments favored a dissolution-reprecipitation mechanism. Percolation columns in combination with a model biofilm can thus be used to study weathering in closed systems. Columns can easily be filled with different minerals and biofilms, the effluent as well as grains can be collected after long-term exposure under axenic conditions and easily analyzed.

Keywords: biotic weathering, flow-through columns, plagioclase, K-feldspar, granite

\section{INTRODUCTION}

As life began to spread onto land at least $1.2 \mathrm{Ga}$ ago, the first settlers were oxygenic cyanobacteria along with various organotrophic microorganisms. Present day sub-aerial (bare) rock surfaces are inhabited by similar microbial communities. Sub-aerial biofilms (SAB) are ubiquitous, self-sufficient, miniature microbial ecosystems that are found on mineral surfaces at all altitudes 
and latitudes. Patchy growth dominated by associations of algae, cyanobacteria, fungi and heterotrophic bacteria are amongst the principal characteristics of SABs. In addition to being one of the principal causes of weathering, SABs also accelerate the decay of cultural heritages (Dornieden et al., 2000a,b; Warscheid and Braams, 2000; de los Ríos and Ascaso, 2005). Microbial colonization of architectural monuments and works of art also causes discoloring as the SAB inhabitants often produce highly colored pigments including carotenoids, chlorophylls and melanins (Gorbushina et al., 1993; Diakumaku et al., 1995; Urzì and Realini, 1998; Gorbushina and Broughton, 2009). Furthermore some organisms induce acidolytic and oxidoreductive corrosion processes, excrete geochemically active substances as siderophores and low molecular weight organic acids, form detrimental crusts and therefore destroy solid materials (Warscheid and Braams, 2000). Limiting or preventing biodeterioration is therefore critical to conserving objects of cultural value.

Various microbes enhance the release of different elements from rocks (Davis et al., 2007; Abdulla, 2009; Bonneville et al., 2011; Brunner et al., 2011; Lapanje et al., 2012; Olsson-Francis et al., 2012). Excreted organic acids and respiration-derived $\mathrm{CO}_{2}$ are often active in these processes (Silverman and Munoz, 1970; Delatorre et al., 1993; Gómez-Alarcón et al., 1994; Machill et al., 1997; Landeweert et al., 2001; Abdulla, 2009; Weber et al., 2011), although fungal hyphae can directly penetrate and widen fissures in rocks (Sterflinger, 2000; Gorbushina et al., 2003; Chertov et al., 2004). The extreme microbial diversity of soil organisms (Jongmans et al., 1997; Landeweert et al., 2001; Schöll et al., 2008; Abdulla, 2009; Bonneville et al., 2009; Rosling et al., 2009; Taylor et al., 2009) and accompanying macroscopic vegetation results in high rates of weathering. As weathering of rocks is the first step in soil formation (Chadwick et al., 1990), surface weathering is an essential component of biogeomorphological processes. Nevertheless, the morphologically simpler microbial ecosystems that prevail on bare rocks also have multiple effects on element cycles (Gorbushina, 2007). The relative simplicity of $\mathrm{SAB}$ communities as compared to microbes in soils means that they are ideal in the study of biotic impact of microbes on the dissolution of minerals. Due to the extreme conditions on bare rock surfaces, only certain stress tolerant microorganisms that can withstand extreme dryness, wide temperature fluctuations, intense solar irradiation and low nutrient availability are able to survive. Often phototrophic cyanobacteria and oligotrophic microcolonial fungi (MCF) initially dominate this ecological niche (Staley et al., 1982; Sterflinger, 1998; Tamaru et al., 2005; Gorbushina, 2007; Knowles and Castenholz, 2008; Ozturk and Aslim, 2010). Both types of organisms are extremely tolerant of many kinds of stress conditions and are therefore involved in biodeterioration of monuments (Gorbushina et al., 1993, 2003; Diakumaku et al., 1995; Ortega-Calvo et al., 1995; Büdel et al., 2004; Olsson-Francis et al., 2012).

Various systems have been proposed to study the dissolution of minerals under different environmental conditions but flowthrough systems result in high aeration and dissolution rates, which are important for cultivation of aerobic microorganisms and ideal for modeling $\mathrm{SAB}$ growth on rocks and minerals. Flow-through percolation columns allow for long-term microbiologically and geochemically stable experiments. Furthermore, quantification of dissolution can be performed on the liquid phase by measuring released elements via spectrometric methods like ICP-MS and ICP-OES (inductively coupled plasma mass spectrometry/optical emission spectrometry) (Olesik, 1991). Changes in the mineral phase can be analyzed via spectroscopic methods including EDX (energy dispersive X-ray spectroscopy), SEM (scanning electron microscope) or TEM (transmission electron microscope) (Eggert, 2005). Additionally, the solid mineral phase can be chemically digested and the contents measured by ICP-MS/OES. Degradation of solid phases is often described by "weathering indices" which are the ratios of mobile and immobile elements (Price and Velbel, 2003; Takahashi and Shimaoka, 2012). To be useful, weathering indices must take into account a certain spectrum of mobile elements in the particular mineral and be applicable to as broader range of different rock-types as possible. Two widely accepted indices are the Weathering Index of Parker (WIP) and the Chemical Index of Alteration (CIA), calculated according to Equations (1) and (2). WIP values decrease and CIA values increase with rising degrees of weathering.

$$
\begin{aligned}
\mathrm{WIP}= & 100^{*}\left[\left(2 \mathrm{Na}_{2} \mathrm{O} / 0.35\right)+(\mathrm{MgO} / 0.9)+\left(2 \mathrm{~K}_{2} \mathrm{O} / 0.25\right)\right. \\
& +(\mathrm{CaO} / 0.7)] \\
\mathrm{CIA}= & 100^{*}\left[\mathrm{Al}_{2} \mathrm{O}_{3} /\left(\mathrm{Al}_{2} \mathrm{O}_{3}+\mathrm{CaO}+\mathrm{Na}_{2} \mathrm{O}+\mathrm{K}_{2} \mathrm{O}\right)\right]
\end{aligned}
$$

Equally, the types of rocks used in model weathering studies should be of global relevance and contain components that weather rapidly. Granite, being among the most abundant rock types within the Earth crust and crucially important in the construction of buildings and monuments was an obvious choice. Mica and feldspar are typical components of granite, which have relatively high dissolution rates and are sensitive to microbial degradation (Lasaga et al., 1994; Bonneville et al., 2011).

Finally, reproducible studies of microbial effects on the weathering of rocks are only possible if the number of variables is limited (i.e., simplified laboratory models are a prerequisite) and under well-controlled, laboratory conditions. In a previous study, a laboratory rock-inhabiting biofilm consisting of the heterotrophic MCF Knufia petricola and the nitrogen-fixing cyanobacterium Nostoc punctiforme was established (Gorbushina and Broughton, 2009). Here we used this biofilm to study the biological impact on weathering of granite and related minerals in a new setting of a geomicrobiologically-modified percolation column.

\section{MATERIALS AND METHODS}

\section{Model Biofilm-Starting Cultures and Inoculum Preparation}

Nostoc punctiforme ATCC29133 was kindly supplied by J.M. Meeks (University of California, Davis, CA, USA) (Ekman et al., 2013). Cultures used for the experiments were grown in BG11 medium (Stanier et al., 1971) at $\mathrm{pH} 7.525^{\circ} \mathrm{C}$ and $90 \mu \mathrm{M}$ photons of photosynthetically active light $\mathrm{m}^{2} \mathrm{~s}^{-1}$ for $24 \mathrm{~h} \mathrm{~d}^{-1}$ and shaking 
(160 rpm). Knufia petricola (CBS 123872) was isolated from a weathered marble monument in Athens (Greece) (Nai et al., 2013). Cultures used for the experiments were grown in $2 \%$ malt extract broth [MEB: $2 \%(\mathrm{w} / \mathrm{v})$ malt extract; $0.1 \%(\mathrm{w} / \mathrm{v})$ casein-digested peptone; $2 \%(\mathrm{w} / \mathrm{v}) \mathrm{D}-(+)$-glucose] under shaking $(100 \mathrm{rpm})$ at $25^{\circ} \mathrm{C}$. Both organisms were transferred weekly by diluting 1:100 into fresh media. Seven to $14 \mathrm{~d}$ old cultures were used for the preparation of inocula for rock/mineral dissolution experiments.

To prepare inocula, biomass of both organisms was dispersed in a ball-mill, centrifuged ( $6603 \mathrm{RCF}$ for $15 \mathrm{~min}$ ), the pellets were washed three times and finally re-suspended in $5 \mathrm{mM}$ glucose and $10 \mu \mathrm{M}$ thiamine-hydrochloride for the rock/mineral dissolution experiments. Dispersion of clumped cells was performed in stainless steel beakers containing eight stainless steel beads (ca. 5 $\mathrm{mm}$ diameter) for $10 \mathrm{~min}$ at $30 \mathrm{~Hz}$ (for K. petricola) or with four glass beads for $5 \mathrm{~min}$ at $25 \mathrm{~Hz}$ (for $N$. punctiforme) in a mixer mill (MM400, Retsch GmbH, Haan, Germany).

\section{Experimental Setting}

Percolation experiments were run for $180 \mathrm{~d}$ in columns modified from those used in the investigation of the environmental compatibility of materials (DIN 19528, 2009-01). The glass columns were filled with $750 \mathrm{~g}$ of rock/mineral (mineralogical details in 2.3) with a grain size between 1 and $6 \mathrm{~mm}$, homogenized using a gyro wheel mixer and subsequently subdivided into representative portions using a sample splitter. Rock/mineral-filled columns and solutions were sterilized by autoclaving for $15 \mathrm{~min}$ at $121^{\circ} \mathrm{C}$. Inocula were pipetted into the columns under aseptic conditions. Closed, circulation systems were imposed and a single glass bottle served both as the reservoir for the nutrient solution and as the eluate collector for each column (Figure 1). One L glucose/thiamine solution was supplied from the top by a peristaltic pump (ICP12, IDEX, Oak Harbor, USA) in a parallel mode. The flow-rate was $5.4 \mathrm{~mL}$ $\mathrm{h}^{-1}$ which meant that it took $185 \mathrm{~h}$ for $1 \mathrm{~L}$ nutrient solution to flow through a column. In experiments involving granite, non-inoculated columns ("abiotic experiments") and columns initially inoculated with $10^{5}$ cells of both organisms per g rock ("biotic experiments") were run as triplicates. An additional column was used as abiotic control using MilliQ (MQ) water in place of nutrient solution. Plagioclase and K-feldspar dissolution experiments were performed in the same way using single biotic and abiotic samples. Sterile filters were placed at the inlet and outlet positions of the columns to ensure that microorganisms in biotic experiments remained within the columns.

All rock/mineral dissolution experiments were incubated in Percival climate chambers (Percival Scientific Inc., 505 Research Drive, Perry, IA 50220, USA) at $25^{\circ} \mathrm{C}$ and $90 \mu \mathrm{M}$ photons of photosynthetically active light $\mathrm{m}^{2} \mathrm{~s}^{-1}$ for $24 \mathrm{~h} \mathrm{~d}^{-1}$.

\section{Rocks/Minerals}

Samples used in the weathering experiments were granite blocks (Bauhaus AG, Zug, Switzerland). A chemical and mineralogical characterization of the rock samples was done before use. The overall chemical composition of the granite is given in Table $\mathbf{1}$

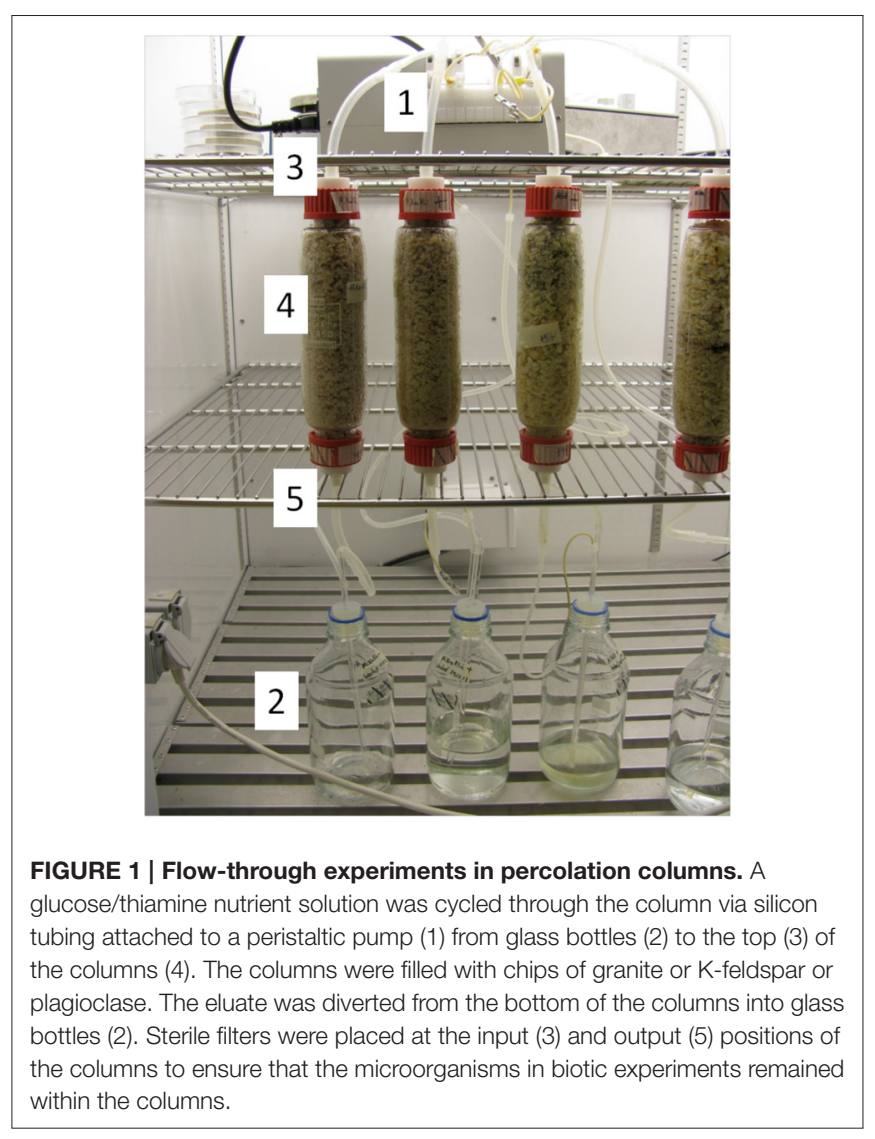

TABLE 1 | Elemental composition of the granite based on ICP-OES or ICP-MS measurements after digestion of the rock material $(n=2)$.

\begin{tabular}{lccccc}
\hline Element & $\begin{array}{c}\text { Concentration } \\
\text { within granite } \\
{[\%]}\end{array}$ & $\begin{array}{c}\text { SD } \\
\text { [\%] }\end{array}$ & Element & $\begin{array}{c}\text { Concentration } \\
\text { within granite } \\
\text { [ppm] }\end{array}$ & $\begin{array}{c}\text { SD } \\
\text { [ppm] }\end{array}$ \\
\hline $\mathrm{Al}$ & 1.59 & 0.24 & $\mathrm{Ba}$ & 92.9 & 36.7 \\
$\mathrm{Ca}$ & 0.03 & $\mathrm{Cd}$ & 0.56 & 0.02 \\
$\mathrm{Fe}$ & 0.49 & $\mathrm{Cd}$ & 5.4 & 0.3 \\
$\mathrm{~K}$ & 0.71 & 0.05 & $\mathrm{Cr}$ & 568 & 3 \\
$\mathrm{Na}$ & 0.05 & $\mathrm{Cu}$ & 7.2 & 1.3 \\
$\mathrm{Si}$ & 0.02 & $\mathrm{Mg}$ & 210 & 32 \\
& 2.37 & & $\mathrm{Mn}$ & 302 & 10 \\
& 27.48 & & $\mathrm{Mo}$ & 43.3 & 1.7 \\
& & & $\mathrm{Ni}$ & 232 & 9 \\
& & & $\mathrm{~Pb}$ & 168 & 1 \\
& & & $\mathrm{Sb}$ & 5.5 & 0.5 \\
& & & $\mathrm{Sr}$ & 72.5 & 6.1 \\
& & & $\mathrm{~V}$ & 3.7 & 0.1 \\
& & & $\mathrm{Zn}$ & 41.5 & 3.9
\end{tabular}

SD, standard deviation.

illustrating more than 2-fold higher amounts of $\mathrm{K}$ as compared to $\mathrm{Na}$.

Polished granite sections contained a plagioclase with an elemental composition toward the albite end member $\left(\mathrm{NaAlSi}_{3} \mathrm{O}_{8}\right)$ (Table 2), a K-rich feldspar $\left(\mathrm{KAlSi}_{3} \mathrm{O}_{8}\right)$, quartz $\left(\mathrm{SiO}_{2}\right)$ and biotite $\left(\mathrm{K}(\mathrm{Mg}, \mathrm{Fe})_{3} \mathrm{AlSi}_{3} \mathrm{O}_{10}(\mathrm{~F}, \mathrm{OH})_{2}\right)$ as mica group. Sporadically, magnetite $\left(\mathrm{Fe}_{3} \mathrm{O}_{4}\right)$, titanite $\left(\mathrm{CaTiSiO}_{5}\right)$, 
TABLE 2 | Elemental composition of feldspars within the granite used before exposition to the experimental conditions, based on EDX measurements.

\begin{tabular}{llcc}
\hline Mineral & Element & $\begin{array}{c}\text { Concentration within } \\
\text { mineral [\%] }\end{array}$ & SD [\%] \\
\hline K-feldspar & $\mathrm{Al}$ & 17.92 & 0.31 \\
& $\mathrm{Ca}$ & 0.10 & 0.05 \\
& $\mathrm{Fe}$ & 0.15 & 0.16 \\
& $\mathrm{~K}$ & 21.94 & 2.36 \\
& $\mathrm{Mg}$ & 0.12 & 0.41 \\
& $\mathrm{Na}$ & 2.89 & 1.60 \\
& $\mathrm{Si}$ & 56.83 & 0.83 \\
\hline \multirow{3}{*}{ Plagioclase } & $\mathrm{Al}$ & 21.03 & 0.88 \\
& $\mathrm{Ca}$ & 2.99 & 1.48 \\
& $\mathrm{Fe}$ & 0.12 & 0.08 \\
& $\mathrm{~K}$ & 0.83 & 0.56 \\
& $\mathrm{Na}$ & 15.03 & 1.14 \\
& $\mathrm{Si}$ & 59.98 & 1.74 \\
\hline
\end{tabular}

(a) Data for the observed K-rich feldspar $(n=13)$ indicating a mineralogy toward the microcline end member. (b) Data for the observed plagioclase $(n=21)$ indicating a mineralogy toward the albite end member.

ilmenite $\left(\mathrm{FeTiO}_{3}\right)$, zircon $\left(\mathrm{ZrSiO}_{4}\right)$, calcite $\left(\mathrm{CaCO}_{3}\right)$ and apatite $\left(\mathrm{Ca}_{10}\left(\mathrm{PO}_{4}\right)_{6}(\mathrm{OH}, \mathrm{F}, \mathrm{Cl})_{2}\right)$ were also found. The K-rich feldspar was microporous with an elemental composition toward microcline $\left(\mathrm{KAlSi}_{3} \mathrm{O}_{8}\right.$ ) but containing low amounts of $\mathrm{Na}$. Chloritization, the transformation of biotite into chlorite $\left((\mathrm{Mg}, \mathrm{Fe})_{3}(\mathrm{Si}, \mathrm{Al})_{4} \mathrm{O}_{10}(\mathrm{OH})_{2}(\mathrm{Mg}, \mathrm{Fe})_{3}(\mathrm{OH})_{6}\right)$, was observed in the peripheral zones of the grains. Plagioclase showed a central sericite formation $\left(\mathrm{KAl}_{2}(\mathrm{OH}, \mathrm{F})_{2} \mathrm{AlSi}_{3} \mathrm{O}_{10}\right)$ through $\mathrm{K}$ accumulation (sericitization).

As the presumably best weatherable minerals within the granite were plagioclase and the K-rich feldspar, these minerals (obtained from Rheinisches Mineralien-Kontor $\mathrm{GmbH}$, Bonn, Germany) were used in additional experiments within the percolation columns. The plagioclase used contained small inclusions with a more microcline-like chemistry, the K-feldspar used contained albite-like inclusions with an estimated fraction of $20-30 \%$.

The original rock material was crushed to small grains using a jaw crusher (BB 300, Retsch GmbH, Haan, Germany), rinsed with MQ water to remove fine dust, dried and sieved to obtain grain sizes between 1 and $6 \mathrm{~mm}$. To ensure a homogeneous distribution of the varying grain sizes within different samples the mineral grains were homogenized and sub-divided by a rotary sample divider (PT 100, Retsch $\mathrm{GmbH}$ ) and collected in glass vessels. Then, the homogenized materials were transferred to the incubation columns.

\section{Biological Analyses}

Cell numbers were quantified using both qPCR (quantitative polymerase chain reaction) with specific primer pairs and the corresponding PCR protocols (Sherwood and Presting, 2007; Bates and Garcia-Pichel, 2009) as well as by viable counts for $K$. petricola and by measuring chlorophyll a (Chl a) for $N$. punctiforme [Meeks and Cohen (Meeks and Castenholz, 1971; Cohen et al., 1994)]. Unknown amounts of DNA were estimated by calibrating DNA extracts with known numbers of each organism.

\section{Chemical Analysis}

Analyses of the mineralogical and elemental composition of polished sections of rock/mineral grains were performed by microprobe recording and EDX measurements using a JXA8230 SuperProbe Electron Probe Microanalyzer (JEOL Ltd, ShinSuzuharu BLDG. 3F 2-8-3 Akebono-cho, Tachikawa, Tokyo 1900012, Japan) ( $n$ between 13 and 21) on clearly differentiated mineral fractions of the polished sections. Polished mineral sections were compared by scanning electron microscopyenergy-dispersive X-ray spectroscopy SEM-EDX (XL30, 5350 NE Dawson Creek Drive, Hillsboro, Oregon 97124 USA) and transmission electron microscopy- energy-dispersive X-ray (TEM-EDX)(CM12, Philips, Amsterdam, Netherlands) in central and peripheral positions of the polished sections before and after imposition of the treatments. Stimulation of the emission of characteristic X-rays was performed using a $5 \mu \mathrm{m}$ thick electron beam at $15 \mathrm{kV}$ for $10 \mathrm{~s}$, while TEM-EDX stimulation was at $120 \mathrm{kV}$ for $300 \mathrm{~s}$. With some samples, microprobe-EDX measurements were additionally performed $(15 \mathrm{kV}$, five times for $2 \mathrm{~s}$ at the same position with subsequent averaging). Analyses of the total chemical composition were done by ICP-OES (ICAP 7400 Duo, Thermo Fisher Scientific Inc., Waltham, MA 02451, USA) or depending on the concentration by ICP-MS (ICAP$\mathrm{Q}$, Thermo Fisher Scientific) after acid digestion of powdered sample materials both before and after dissolution experiments. To do this, $0.2 \mathrm{~g}$ of ground rock material was digested with an acid mixture $\left(4 \mathrm{~mL} 65 \% \mathrm{HNO}_{3} ; 2 . \mathrm{mL} 32 \% \mathrm{HCl}\right.$ and $1 \mathrm{~mL} 48 \%$ $\mathrm{HF})$ in a microwave oven $\left(1 \mathrm{~h}\right.$, maximum temperature $\left.210^{\circ} \mathrm{C}\right)$. To minimize the danger of HF and complex formation of barely soluble fluorides, $10 \mathrm{~mL}$ cold saturated boric acid was added. Weathering indices WIP and CIA were calculated according to Fiantis et al. (2010) using the data obtained by ICP-OES or ICP-MS analysis of solid mineral phases. Before and after $\mathrm{pH}$ measurements of the liquid phase were taken with a $\mathrm{pH}$ meter. Elemental concentrations in the eluted materials were determined after 45 and 180 d incubation by ICP-OES or ICP-MS measurement after acidification of the eluate with concentrated $\mathrm{HNO}_{3}$. External calibration with matrix matching was used for all eluted and digested samples.

\section{RESULTS}

\section{Experiments with Granite}

Abiotic experiments remained aseptic while the number of cells of both organisms increased during $180 \mathrm{~d}$ experimental period in the inoculated columns (Figure 2). Biofilm growth was distributed over mineral fragments in patches, both partners were present in the layers near to the glass as well as in the deeper regions of columns. Permanent circulation/percolation of the medium has supported even distribution of cells and especially of their metabolic products in the percolation columns. qPCRbased estimations and Chla measurements indicated similar 
numbers of $N$. punctiforme, but with $K$. petricola the DNAbased methods gave clearly higher numbers than viable counts (Figure 2), perhaps indicating lack of viability.

It is clear that even with short incubation times (45 d), seven elements were released from the granite. In decreasing quantity

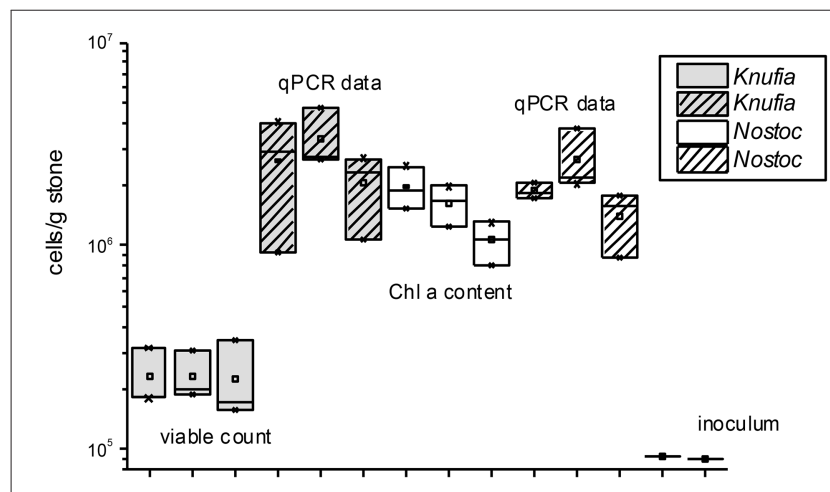

FIGURE 2 | Estimated numbers $(n=3)$ of $K$. petricola and $\boldsymbol{N}$. punctiforme based on qPCR data (both organisms), viable counts ( $K$. petricola) and Chla contents (N. punctiforme). Box plots show triplicate values as cross lines and mean values as squares, the inoculum cell number was the same for all biotic samples and is shown as a cross line. these were $\mathrm{Ca}>\mathrm{Na}>\mathrm{K}>\mathrm{Mg}>\mathrm{Mn}>\mathrm{Zn}>\mathrm{Ba}$. Longer incubation times resulted in greater accumulation of the elements in the eluate (Figure 3). Perhaps surprisingly though only Mn, $\mathrm{Mg}$ and $\mathrm{Ca}$ concentrations were higher for the biotic experiments than the abiotic ones (Figures 3A,B). In other words $\mathrm{Ba}, \mathrm{K}$, and $\mathrm{Zn}$ were released from the minerals by MQ water or sterile medium alone (Figures 3B,C).

SEM-EDX analyses of polished sections showed Ca depletion near the granite surface (Figure 4). CIA weathering indices were generally higher after the experiments as well in biotic as opposed to abiotic conditions (Table 3). Unfortunately, the variance in weathering indices was too high to permit definite conclusions. Similarly, the $\mathrm{pH}$ of the eluates ranged from 5.6 initially to 5.5 after $180 \mathrm{~d}$ and differences between biotic and abiotic conditions were not observed.

\section{Experiments with Plagioclase and K-feldspar}

Again, the abiotic treatments remained aseptic while both the cyanobacterium and the fungus grew in the inoculated columns. $\mathrm{Ca}, \mathrm{K}$, and $\mathrm{Na}$ were released from both minerals over the $180 \mathrm{~d}$ experimental period. $\mathrm{Ca}$ and $\mathrm{Na}$ were especially rapidly released from plagioclase (for $\mathrm{Ca} \approx 2$ orders of magnitude higher than

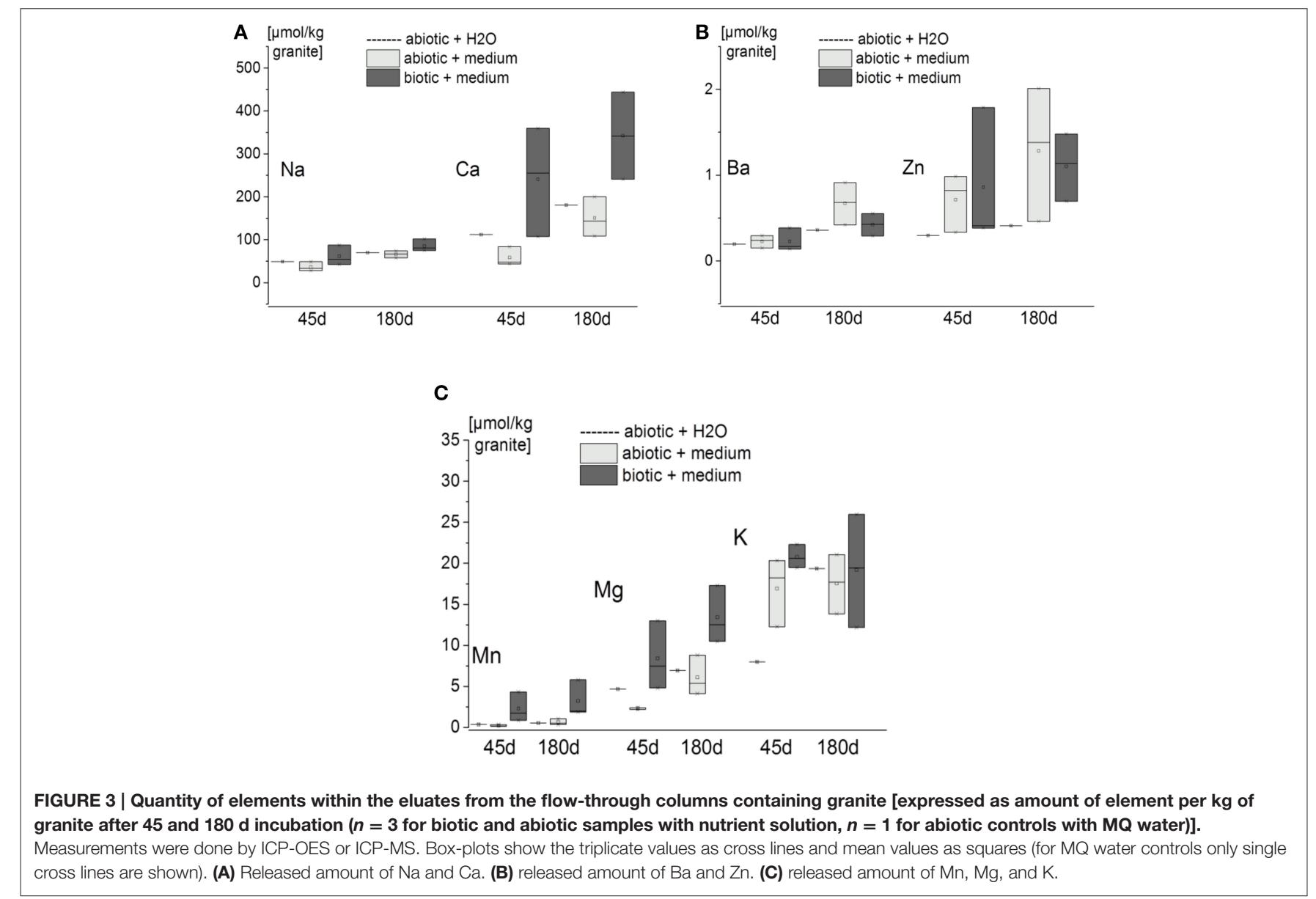




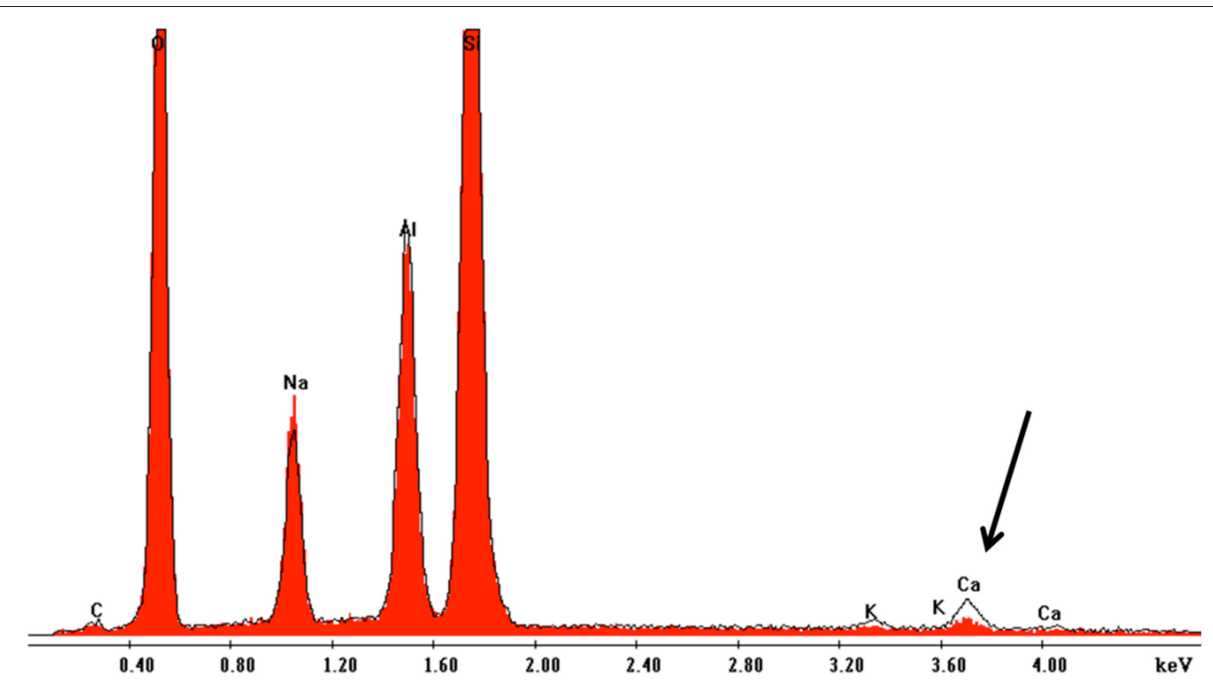

FIGURE 4 | Overlay of EDX spectra near the surface and in the center of granite grains after $180 \mathrm{~d}$ incubation in flow-through columns containing $K$. petricola and $\mathbf{N}$. punctiforme. The spectrum marked in red shows the situation near the mineral surface while the black edging shows the spectrum for the central part of mineral. The black arrow indicates Ca depletion near to the mineral surface.

TABLE 3 | Calculated weathering indices CIA and WIP.

\begin{tabular}{lcccc}
\hline Sample & CIA index & SD & WIP index & SD \\
\hline Before & 21 & - & 4440 & - \\
abiotic control MQ water after & 24 & - & 4310 & - \\
abiotic samples after & 32 & 12 & 4086 & 57 \\
biotic samples after & 39 & 12 & 4160 & 225 \\
\hline
\end{tabular}

in $\mathrm{K}$-feldspar) although $\mathrm{K}$ release was slightly higher in $\mathrm{K}$ feldspar (Figure 5). Ca release was enhanced in the biotic samples containing plagioclase. With K-feldspar, the release also included $\mathrm{Na}$. Ca depletion was confirmed in polished sections of samples via SEM-EDX analyses. A darker area near the surface of the mineral grains within the polished sections occurred down to $\geq 5$ $\mu \mathrm{m}$ (Figure 6A). A line-scan for Ca concentrations starting from the darker to the lighter area within the mineral grains revealed an abrupt rise in $\mathrm{Ca}$ concentration at the border between the two areas (Figure 6B). Such an abrupt change in concentration was not observed in line-scans of $\mathrm{Na}$ and only slightly for $\mathrm{Al}$. These findings were supported by microprobe analyses showing almost complete depletion of $\mathrm{Ca}$ and a slight depletion of $\mathrm{Al}$ in the darker area with $\mathrm{Na}$ being constant compared to the lighter area. Depletion of Na within plagioclase and $\mathrm{K}$ within $\mathrm{K}$-feldspar was shown via TEM-EDX analyses to occur in the direct vicinity of the surface at $\leqq 2 \mu \mathrm{m}$ depth (Figure 7 ).

\section{DISCUSSION}

Although the absolute amount of $\mathrm{K}$ within the granite was 2-fold higher than $\mathrm{Na}$ and 10-fold higher than $\mathrm{Ca}$ (Table 1), release of $\mathrm{Ca}$ and $\mathrm{Na}$ exceeded the one of $\mathrm{K}$ explicitly during incubation in the flow-through columns with $\mathrm{Ca}$ being more released than $\mathrm{Na}$ (Figure 3). Considering the mainly found minerals within the granite used and known mineral dissolution rates from other studies (Lasaga et al., 1994), plagioclase is expected to be dissolved first, followed by other feldspars, micas and finally quartz (White, 2008). This is in agreement with the found amounts of elements in eluates, as $\mathrm{Ca}$ and $\mathrm{Na}$ are most probably released from the plagioclase obeying faster dissolution kinetics and resulting in higher final concentrations compared to presumably K-feldspar- and biotite-derived $\mathrm{K}, \mathrm{Mg}$ and $\mathrm{Mn}$. This is additionally supported by experiments using only plagioclase or K-feldspar: for plagioclase Ca concentrations within eluates were 10 -fold and $\mathrm{Na}$ concentrations 5 -fold higher than the respective values for granite, indicating that within the latter most of the released $\mathrm{Ca}$ and $\mathrm{Na}$ derived from its plagioclase. In granite other minerals with much lower dissolution rates like quartz occupy a relevant part of the surface area and reduce therefore the overall release of $\mathrm{Ca}$ and $\mathrm{Na}$. If only plagioclase is provided as weathering substrate, the relative area with faster dissolving minerals is increased resulting in comparatively higher $\mathrm{Ca}$ concentrations in the eluate. For K-feldspar experiments $\mathrm{K}$ concentrations in the eluates were within the same range as for granite experiments despite the fact, that only K-feldspar was offered as weathering substrate, indicating that a relevant part of the released $\mathrm{K}$ in the granite experiments derived from other minerals than $\mathrm{K}$-feldspar. Biotite is the most likely alternative $\mathrm{K}$ containing mineral within granite that may have contributed to the amount of released $\mathrm{K}$. The concomitant release of $\mathrm{Mg}$ and $\mathrm{Mn}$ (Figure 3) supports this hypothesis.

Within plagioclases the dissolution rates increase with increasing anorthite fractions implying a faster release of $\mathrm{Ca}$ (Huang and Kiang, 1972; Oxburgh et al., 1994). Faster release of Ca might be reflected also in larger depletion distances from the surface to the center of mineral grains. This would explain why $\mathrm{Ca}$ is depleted up to more than $5 \mu \mathrm{m}$ into the mineral grains, whereas $\mathrm{Na}$ and $\mathrm{K}$ depletion are detected only in less than $2 \mu \mathrm{m}$ 

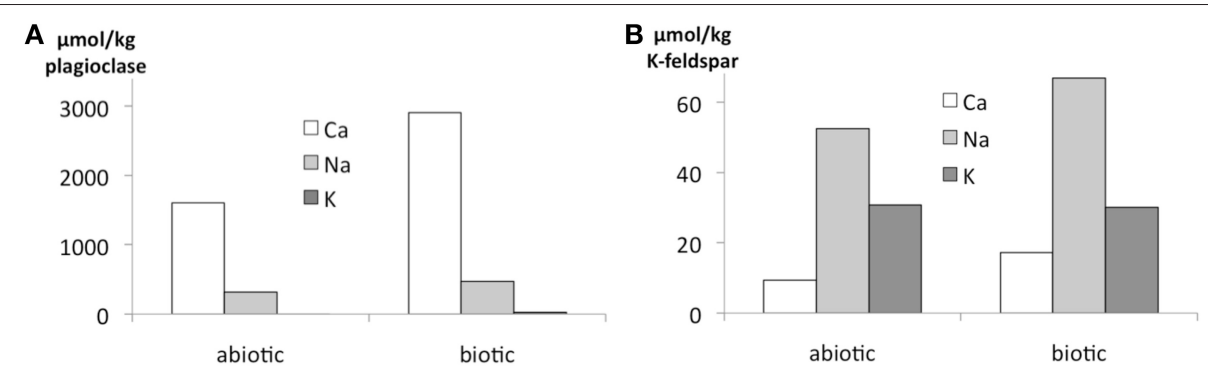

FIGURE 5 | Release of elements in the flow-through experiments expressed as amount per kg of biofilm-incubated plagioclase (A) and K-feldspar (B) after $\mathbf{1 8 0} \mathbf{d}$ incubation. Measurements were done by ICP-OES or ICP-MS for one biotic and one abiotic sample with nutrient solution.

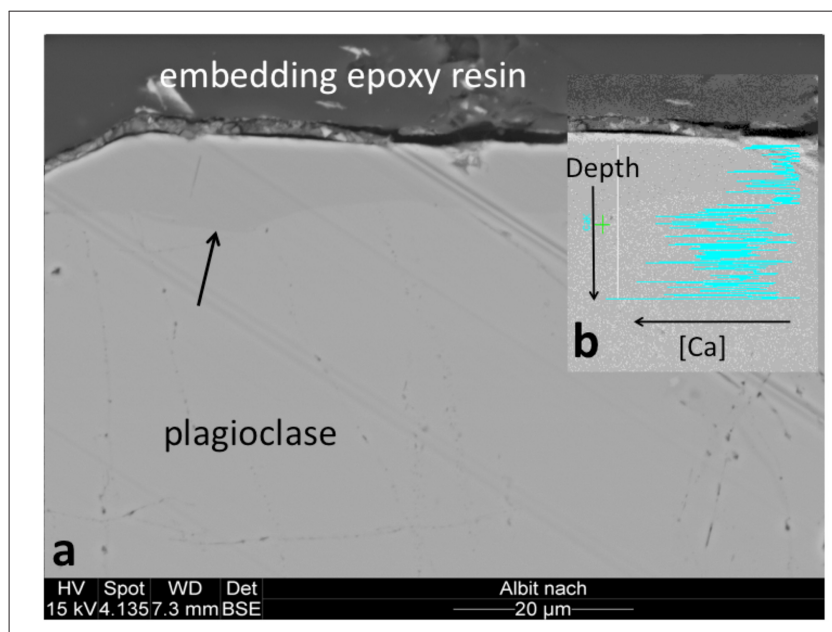

FIGURE 6 | Ca depletion near the surface of plagioclase grains. (A) Microprobe recording of a polished plagioclase grain section with a darker area near the surface is indicated by a black arrow. (B) Line-scan of the Ca concentration starting from the surface and crossing the border to the lighter area positioned more centrally (Ca concentration increases from right to left).

distance from the mineral surface in examined polished mineral sections.

In granite the release of $\mathrm{Ca}, \mathrm{Mg}$, and $\mathrm{Mn}$ was biotically enhanced (Figures 3A,C), for $\mathrm{K}$ there was no difference compared to abiotic samples with regard to the concentrations in the eluate (Figure $3 \mathrm{C}$ ). $\mathrm{Ca}^{2+}, \mathrm{Na}^{+}, \mathrm{K}^{+}$, and $\mathrm{Mg}^{2+}$ are the most abundant metal ions within biology (Cowan, 1991) and can be both absorbed in the biofilm/biofilm matrix as well as incorporated into the cells. $\mathrm{Mg}$ dependent enzymes participate in general metabolic and essential nucleotide processing reactions in all organisms (Cowan, 2002). Ca is of crucial importance for calmodulin and calcineurin in eukaryotes (Kraus and Heitman, 2003) as well as for various processes like chemotaxis, DNA replication, phospholipid synthesis and protein phosphorylation in prokaryotes (Norris et al., 1991). Na and K are important electrolytes maintaining electrochemical gradients within cells and contributing to charge neutralization (Black et al., 1994). As these elements are essential for various cell processes, they are expected to occur at least in low amounts within all organisms and are found there also (Li, 1984). So, dissolution of rocks like granite can not only be enhanced in the presence of microorganisms, but the concentration of released elements in solution can be changed also by its accumulation in organisms. If released $\mathrm{K}$ would be accumulated within microbial cells in significant amounts, its detection within the eluate would be decreased and a biotic enhancement of $\mathrm{K}$ release would be masked. Such an effect could have been caused in the presented experiments by $\mathrm{K}$ accumulation of 5-10 $\mu \mathrm{m}$. Data for measured cell numbers lead to an estimated weight of $0.5 \mathrm{~g}$ for the final biomass. K accumulations of 5-10 $\mu \mathrm{m}$ would correspond to $0.1-$ $0.2 \mathrm{mg} \mathrm{K}$ per g cells. $\mathrm{K}$ accumulations of this range and even higher have been shown for mycorrhizal fungi (Wallander et al., 2002, 2003). The estimated weight of the inoculum is $15 \mathrm{mg}$. The content of the elements $\mathrm{Ca}, \mathrm{Na}, \mathrm{Mg}, \mathrm{Mn}$, and $\mathrm{K}$ within microorganisms related to K. petricola and N. punctiforme (Gao, 1998; Tashpulatov et al., 2000) makes a relevant contribution of the starting biomass to the final element concentrations within the eluate implausible. The measured enhancement of mineral dissolution in biotic samples is therefore assumed to be caused by growing microorganisms. As no direct physical attacks by fungal hyphae or cyanobacterial filaments were observable via microscopical methods (SEM, TEM, light microscopy) within mineral samples, an indirect process resulting from microbial metabolism is suggested. For example, production of organic acids or respiration-derived $\mathrm{CO}_{2}$ would lower the $\mathrm{pH}$, which is a possible factor in biodeterioration of minerals (Delatorre et al., 1993; Gómez-Alarcón et al., 1994; Machill et al., 1997; Weber et al., 2011). The fact that $\mathrm{pH}$ decreased only slightly and in the same way in all experiments despite varying extent of dissolution (Figure 3) is not contradictory with this explanation as $\mathrm{pH}$ values in the direct micro-environment of cells between a biofilm and its substrate can differ significantly from those in the macro-environment (Bonneville et al., 2011). The lower cell numbers for $K$. petricola in viable counts as compared to qPCR data (Figure 2) could imply that a significant part of the fungal cells died during the experiments or was finally in an uncultivable state. This would not exclude a biotic influence of these cells, as a release of acidifying metabolites would be still possible and could have occurred also in an earlier stage during the experiment. The mere presence of various organic ligands is known to increase element release from granites (Neaman et al., 2006; Hausrath et al., 2009), and the growth of the model biofilm that has steadily increased its biomass during 

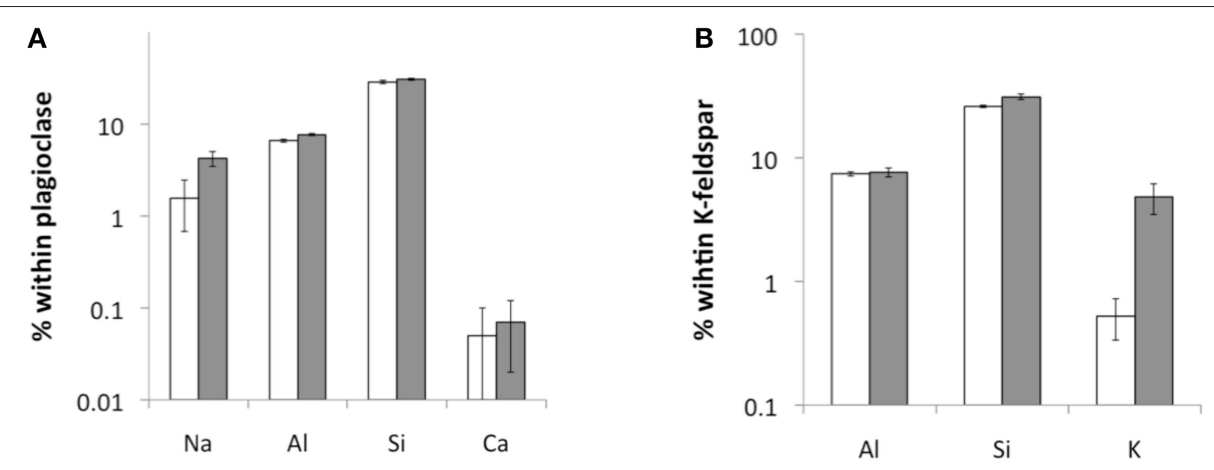

FIGURE 7 | TEM-EDX measurements of element concentrations within plagioclase (A) and K-feldspar (B) near the surface (white) and 1-2 $\mu \mathrm{m}$ below the surface (gray) $(n=10)$.

the experiment is unequivocally connected to the production of various accompanying metabolites.

The abrupt decrease of $\mathrm{Ca}$ concentration in peripheral mineral areas observed in polished plagioclase sections favors an interface-coupled dissolution-reprecipitation mechanism on the interface between mineral and environment as described recently in silicates (Putnis, 2009; Hellmann et al., 2012; RuizAgudo et al., 2014). A leaching mechanism would have resulted in the formation of a Ca concentration gradient, which was not observed. This implies dissolution of $\mathrm{Ca}$-containing plagioclase and reprecipitation of a plagioclase with much less $\mathrm{Ca}$ and a composition more toward the albite end member. This process, known as albitisation, occurs widespread in natural rock types and is especially related to hydrothermal alteration (Hövelmann et al., 2010) as well as low-temperature water-rock exchange during burial diagenesis of feldspar-bearing sandstones (Perez and Boles, 2005).

The calculated WIP and CIA weathering indices indicate increasing weathering after $180 \mathrm{~d}$ incubation within the flowthrough columns and for percolation with the used nutrient solution as compared to MQ water. A significant difference between biotic and abiotic samples was not observed, probably due to the short incubation time.

\section{CONCLUDING REMARKS}

The bipartite model laboratory biofilm including Knufia petricola A95 and N. punctiforme (Gorbushina and Broughton, 2009; Seiffert et al., 2014) is capable of growing symbiotically and interacting with mineral substrates. The present work demonstrates that dissolution of granite, plagioclase and K-feldspar is enhanced in the presence of model biofilms under flow-through conditions. This effect is most likely indirectly caused by released metabolites of the microorganisms. Interestingly, the major nutrient $\mathrm{Ca}$ is preferentially released from Na-rich feldspar grains. The dissolution mechanisms could be explained by dissolution-reprecipitation. The mechanism of the biodeteriorating process still has to be elucidated-and a combination of a genetically amenable model fungal/phototroph biofilm (Gorbushina and Broughton, 2009; Seiffert et al., 2014) grown in percolation columns offers a new instrument of biologically as well as geochemically precise quantification-based studies. A statistically-relevant number of grains that are exposed to biofilm-induced weathering allows for a quantifying geochemical analysis of the process, while microscopic/analytic analysis of single grains can be used to demonstrate local activity of single cells and their excreted matrices. Acidification in the microenvironment between biofilm and mineral surface is a hypothesis that can be tested via high-spatial resolution $\mathrm{pH}$ measurements. Genetic amenability of both model biofilm partners (Noack-Schönmann et al., 2014) will be used to study different combinations of genes possibly involved in mineral weathering.

\section{AUTHOR CONTRIBUTIONS}

FS performed all the experiments, actively designed the study, and intensively worked on the manuscript. NB and UK provided the know-how on the percolation columns and conducted and interpreted chemical analysis by ICP-OES and ICP-MS at the BAM. RM supported the choice of mineral substrates, performed mineralogical characterization of the rock samples and interpreted the data. AAG conceived the study, participated in its design, and helped to interpret the data and write the manuscript. All authors read and approved the final manuscript.

\section{ACKNOWLEDGMENTS}

This work was funded by the Federal Institute for Materials Research and Testing. We thank Ines Feldmann for her help with SEM-EDX measurements, Peter Schubert-Bischoff for TEM-EDX measurements and polished sections preparation and Katja Nordhauß for ICP-OES and ICP-MS measurements. Furthermore we thank Kerstin Erdmann, Andreas Krüger and Renate Helm for their help with the preparation and homogenization of the rock material. William J. Broughton is thanked for his valued help in English editing of the manuscript. 


\section{REFERENCES}

Abdulla, H. (2009). Bioweathering and biotransformation of granitic rock minerals by actinomycetes. Microb. Ecol. 58, 753-761. doi: 10.1007/s00248-009-9549-1

Bates, S. T., and Garcia-Pichel, F. (2009). A culture-independent study of freeliving fungi in biological soil crusts of the Colorado Plateau: their diversity and relative contribution to microbial biomass. Environ. Microbiol. 11, 56-67. doi: 10.1111/j.1462-2920.2008.01738.x

Black, C. B., Huang, H. W., and Cowan, J. A. (1994). Biological coordination chemistry of magnesium, sodium, and potassium-ions - protein and nucleotide-binding sites. Coord. Chem. Rev. 135, 165-202. doi: 10.1016/00108545(94)80068-5

Bonneville, S., Morgan, D. J., Schmalenberger, A., Bray, A., Brown, A., Banwart, S. A., et al. (2011). Tree-mycorrhiza symbiosis accelerate mineral weathering: evidences from nanometer-scale elemental fluxes at the hypha-mineral interface. Geochim. Cosmochim. Acta 75, 6988-7005. doi: 10.1016/j.gca.2011.08.041

Bonneville, S., Smits, M. M., Brown, A., Harrington, J., Leake, J. R., Brydson, R., et al. (2009). Plant-driven fungal weathering: early stages of mineral alteration at the nanometer scale. Geology 37, 615-618. doi: 10.1130/G25699A.1

Brunner, I., Plötze, M., Rieder, S., Zumsteg, A., Furrer, G., and Frey, B. (2011). Pioneering fungi from the Damma glacier forefield in the Swiss Alps can promote granite weathering. Geobiology 9, 266-279. doi: 10.1111/j.14724669.2011.00274.x

Büdel, B., Weber, B., Kühl, M., Pfanz, H., Sültemeyer, D., and Wessels, D. (2004). Reshaping of sandstone surfaces by cryptoendolithic cyanobacteria: bioalkalization causes chemical weathering in arid landscapes. Geobiology 2, 261-268. doi: 10.1111/j.1472-4677.2004.00040.x

Chadwick, O. A., Brimhall, G. H., and Hendricks, D. M. (1990). From a black to a gray box - a mass balance interpretation of pedogenesis. Geomorphology 3, 369-390. doi: 10.1016/0169-555X(90)90012-F

Chertov, O., Gorbushina, A., and Deventer, B. (2004). A model for microcolonial fungi growth on rock surfaces. Ecol. Model. 177, 415-426. doi: 10.1016/j.ecolmodel.2004.02.011

Cohen, M. F., Wallis, J. G., Campbell, E. L., and Meeks, J. C. (1994). Transposon mutagenesis of Nostoc sp. strain ATCC 29133, a filamentous cyanobacterium with multiple cellular differentiation alternatives. Microbiology 140( $\mathrm{Pt} \mathrm{12}$ ), 3233-3240. doi: 10.1099/13500872-140-12-3233

Cowan, J. A. (1991). Metallobiochemistry of magnesium - coordination-complexes with biological substrates - site specificity, kinetics and thermodynamics of binding, and implications for activity. Inorg. Chem. 30, 2740-2747. doi: $10.1021 /$ ic00013a008

Cowan, J. A. (2002). Structural and catalytic chemistry of magnesium-dependent enzymes. Biometals 15, 225-235. doi: 10.1023/A:1016022730880

Davis, K. J., Nealson, K. H., and Luttge, A. (2007). Calcite and dolomite dissolution rates in the context of microbe-mineral surface interactions. Geobiology 5, 191-205. doi: 10.1111/j.1472-4669.2007.00112.x

Delatorre, M. A., Gómez-Alarcón, G., Vizcaino, C., and Garcia, M. T. (1993). Biochemical-mechanisms of stone alteration carried out by filamentous fungi living in monuments. Biogeochemistry 19, 129-147. doi: 10.1007/BF00 000875

de los Ríos, A., and Ascaso, C. (2005). Contributions of in situ microscopy to the current understanding of stone biodeterioration. Int. Microbiol. 8, 181-188. Available online at: http://scielo.isciii.es/scielo.php?pid=S1139$67092005000300005 \&$ script $=$ sci_arttext\&tlng $=\mathrm{pt}$

DIN 19528 (2009-01). Leaching of Solid Materials - Percolation Method for the Joint Examination of the Leaching Behaviour of Organic and Inorganic Substances for Materials with a Particle Size upto $32 \mathrm{~mm}$ - Basic Characterization Using a Comprehensive Column Test and Compliance Test Using a Quick Column Test. Deutsches Institut für Normung, German Standardization Organization, Berlin.

Diakumaku, E., Gorbushina, A. A., Krumbein, W. E., Panina, L., and Soukharjevski, S. (1995). Black fungi in marble and limestones - an aesthetical, chemical and physical problem for the conservation of monuments. Sci. Total Environ. 167, 295-304. doi: 10.1016/0048-9697(95)04590-W

Dornieden, T., Gorbushina, A. A., and Krumbein, W. E. (2000a). Biodecay of cultural heritage as a space/time-related ecological situation - an evaluation of a series of studies. Int. Biodeter. Biodegrad. 46, 261-270. doi: 10.1016/S09648305(00)00107-4

Dornieden, T., Gorbushina, A. A., and Krumbein, W. E. (2000b). "Patina - physical and chemical interactions of sub-aerial biofilms with objects of art," in $O f$ Microbes and Art: The Role of Microbial Communities in the Degradation and Protection of Cultural Heritage, eds O. Ciferri, P. Tiano, and G. Mastromei (New York, NY; Boston, MA; Dordrecht; London; Moscow: Kluwer), 105-119.

Eggert, F. (2005). Standardfreie Elektronenstrahl-Mikroanalyse. Books on Demand.

Ekman, M., Picossi, S., Campbell, E. L., Meeks, J. C., and Flores, E. (2013). A Nostoc punctiforme sugar transporter necessary to establish a Cyanobacteriumplant symbiosis. Plant Physiol. 161, 1984-1992. doi: 10.1104/pp.112. 213116

Fiantis, D., Nelson, M., Shamshuddin, J., Goh, T. B., and Van Ranst, E. (2010). Determination of the geochemical weathering indices and trace elements content of New Volcanic ash deposits from Mt. Talang (West Sumatra) Indonesia. Eur. Soil Sci. 43, 1477-1485. doi: 10.1134/S1064229310130077

Gao, K. (1998). Chinese studies on the edible blue-green alga, Nostoc flagelliforme: a review. J. Appl. Phycol. 10, 37-49. doi: 10.1023/A:1008014424247

Gómez-Alarcón, G., Munoz, M. L., and Flores, M. (1994). Excretion of organicacids by fungal strains isolated from decayed sandstone. Int. Biodeter. Biodegr. 34, 169-180. doi: 10.1016/0964-8305(94)90006-X

Gorbushina, A. A. (2007). Life on the rocks. Environ. Microbiol. 9, 1613-1631. doi : 10.1111/j.1462-2920.2007.01301.x

Gorbushina, A. A., and Broughton, W. J. (2009). Microbiology of the atmosphererock interface: how biological interactions and physical stresses modulate a sophisticated microbial ecosystem. Annu. Rev. Microbiol. 63, 431-450. doi: 10.1146/annurev.micro.091208.073349

Gorbushina, A. A., Krumbein, W. E., Hamman, C. H., Panina, L., Soukharjevski, S., and Wollenzien, U. (1993). Role of black fungi in colour change and biodeterioration of antique marbles. Geomicrobiol. J. 11, 205-221. doi: 10.1080/01490459309377952

Gorbushina, A. A., Krumbein, W. E., Rullkötter, J., and Volkmann, M. (2003). How and why do rocks turn black - A history of surface biogeochemistry. Geochim. Cosmochim. Acta 67:A123.

Hausrath, E. M., Neaman, A., and Brantley, S. L. (2009). Elemental release rates from dissolving basalts and granite with and without organic ligands. Am. J. Sci. 309, 633-660. doi: 10.2475/08.2009.01

Hellmann, R., Wirth, R., Daval, D., Barnes, J. P., Penisson, J. M., Tisserand, D., et al. (2012). Unifying natural and laboratory chemical weathering with interfacial dissolution-reprecipitation: a study based on the nanometer-scale chemistry of fluid-silicate interfaces. Chem. Geol. 294-295, 203-216. doi: 10.1016/j.chemgeo.2011.12.002

Hövelmann, J., Putnis, A., Geisler, T., Schmidt, B. C., and Golla-Schindler, U. (2010). The replacement of plagioclase feldspars by albite: observations from hydrothermal experiments. Contribut. Mineral. Petrol. 159, 43-59. doi: 10.1007/s00410-009-0415-4

Huang, W. H., and Kiang, W. C. (1972). Laboratory dissolution of plagioclase feldspars in water and organic-acids at room-temperature. Am. Mineral. 57, 1849-1859.

Jongmans, A. G., van Breemen, N., Lundström, U. P.,van Hees, A. W., Finlay, R. D., and Olsson, M. (1997). Rock-eating fungi. Nature 389, 682-683. doi: $10.1038 / 39493$

Knowles, E. J., and Castenholz, R. W. (2008). Effect of exogenous extracellular polysaccharides on the desiccation and freezing tolerance of rock-inhabiting phototrophic microorganisms. Fems Microbiol. Ecol. 66, 261-270. doi: 10.1111/j.1574-6941.2008.00568.x

Kraus, P. R., and Heitman, J. (2003). Coping with stress: calmodulin and calcineurin in model and pathogenic fungi. Biochem. Biophys. Res. Commun. 311, 1151-1157. doi: 10.1016/S0006-291X(03)01528-6

Landeweert, R., Hoffland, E., Finlay, R. D., Kuyper, T. W., and van Breemen, N. (2001). Linking plants to rocks: ectomycorrhizal fungi mobilize nutrients from minerals. Trends Ecol. Evol. 16, 248-254. doi: 10.1016/S0169-5347(01)02122-X

Lapanje, A., Wimmersberger, C., Furrer, G., Brunner, I., and Frey, B. (2012). Pattern of elemental release during the granite dissolution can be changed by aerobic heterotrophic bacterial strains isolated from damma glacier (central alps) deglaciated granite sand. Microb. Ecol. 63, 865-882. doi: 10.1007/s00248011-9976-7 
Lasaga, A. C., Soler, J. M., Ganor, J., Burch, T. E., and Nagy, K. L. (1994). Chemicalweathering rate laws and global geochemical cycles. Geochim. Cosmochim. Acta 58, 2361-2386. doi: 10.1016/0016-7037(94)90016-7

Li, Y.-H. (1984). Why are the chemical compositions of living organisms so similar? Schweizerische Zeitschrift Hydrologie 46, 177-184. doi: 10.1007/bf02538059

Machill, S., Althaus, K., Krumbein, W. E., and Steger, W. E. (1997). Identification of organic compounds extracted from black weathered surfaces of Saxonean sandstones, correlation with atmospheric input and rock inhabiting microflora. Organ. Geochem. 27, 79-97. doi: 10.1016/S0146-6380(97) 00041-7

Meeks, J. C., and Castenholz, R. W. (1971). Growth and photosynthesis in an extreme thermophile, Synechoccoccus lividus (Cyanophyta). Arch. Mikrobiol. 78, 25. doi: 10.1007/BF00409086

Nai, C., Wong, H. Y., Pannenbecker, A., Broughton, W. J., Benoit, I., de Vries, R. P., et al. (2013). Nutritional physiology of a rock-inhabiting, model micro-colonial fungus from an ancestral lineage of the Chaetothyriales (Ascomycetes). Fungal Genet. Biol. 56, 54-66. doi: 10.1016/j.fgb.2013.04.001

Neaman, A., Chorover, J., and Brantley, S. L. (2006). Effects of organic ligands on granite dissolution in batch experiments at pH 6. Am. J. Sci. 306, 451-473. doi: 10.2475/06.2006.03

Noack-Schönmann, S., Bus, T., Banasiak, R., Knabe, N., Broughton, W. J., Den Dulk-Ras, H., et al. (2014). Genetic transformation of Knufia petricola A95 - a model organism for biofilm-material interactions. AMB Express 4:80. doi: 10.1186/s13568-014-0080-5

Norris, V., Chen, M., Goldberg, M., Voskuil, J., McGurk, G., and Holland, I. B. (1991). Calcium in bacteria: a solution to which problem? Mol. Microbiol. 5, 775-778. doi: 10.1111/j.1365-2958.1991.tb00748.x

Olesik, J. W. (1991). Elemental analysis using ICP-OES and ICP/MS. Anal. Chem. 63, 12A-21A. doi: 10.1021/ac00001a711

Olsson-Francis, K., Simpson, A. E., Wolff-Boenisch, D., and Cockell, C. S. (2012). The effect of rock composition on cyanobacterial weathering of crystalline basalt and rhyolite. Geobiology 10, 434-444. doi: 10.1111/j.14724669.2012.00333.x

Ortega-Calvo, J. J., Arino, X., Hernandez-Marine, M., and Saiz-Jimenez, C. (1995). Factors affecting the weathering and colonization of monuments by phototrophic microorganisms. Sci. Total Environ. 167, 329-341. doi: 10.1016/0048-9697(95)04593-P

Oxburgh, R., Drever, J. I., and Sun, T. (1994). Mechanism of plagioclase dissolution in acid solution at $25^{\circ} \mathrm{C}$. Geochim. Cosmochim. Acta 58, 661-669. doi: 10.1016/0016-7037(94)90496-0

Ozturk, S., and Aslim, B. (2010). Modification of exopolysaccharide composition and production by three cyanobacterial isolates under salt stress. Environ. Sci. Poll. Res. 17, 595-602. doi: 10.1007/s11356-009-0233-2

Perez, R., and Boles, A. R. (2005). An empirically derived kinetic model for albitization of detritic plagioclase. Am. J. Sci. 305, 312-343. doi: 10.2475/ajs.305.4.312

Price, J. R., and Velbel, M. A. (2003). Chemical weathering indices applied to weathering profiles developed on heterogeneous felsic metamorphic parent rocks. Chem. Geol. 202, 397-416. doi: 10.1016/j.chemgeo.2002.11.001

Putnis, A. (2009). Mineral replacement reactions. Rev. Mineral. Geochem. 70, 87-124. doi: 10.2138/rmg.2009.70.3

Rosling, A., Roose, T., Hermann, A. M., Davidson, F. A., Finlay, R. D., and Gadd, G. M. (2009). Approaches to modelling mineral weathering by fungi. Fungal Biol. Rev. 23, 138-144. doi: 10.1016/j.fbr.2009.09.003

Ruiz-Agudo, E., Putnis, C., and Putnis, A. (2014). Coupled dissolution and precipitation at mineral-fluid interfaces. Chem. Geol. 383, 132-146. doi: 10.1016/j.chemgeo.2014.06.007

Schöll, L., Kuyper, T. W., Smits, M. M., Landeweert, R., Hoffland, E., and van Breemen, N. (2008). Rock-eating mycorrhizas: their role in plant nutrition and biogeochemical cycles. Plant Soil 303, 35-47. doi: 10.1007/s11104-007-9513-0

Seiffert, F., Bouchez, J., von Blanckenburg, F., and Gorbushina, A. A. (2014). Microbial colonization of bare rocks: laboratory biofilm enhances mineral weathering. Proc. Earth Plan. Sci. 12, 123-129. doi: 10.1016/j.proeps.2014.08.042

Sherwood, A. R., and Presting, G. G. (2007). Universal primers amplify a 23S rDNA plastid marker in eukaryotic algae and cyanobacteria. J. Phycol. 43, 605-608. doi: 10.1111/j.1529-8817.2007.00341.x

Silverman, M. P., and Munoz, E. F. (1970). Fungal attack on rock - solubilization and altered infrared spectra. Science 169, 985. doi: 10.1126/science.169.3949.985

Staley, J. T., Palmer, F., and Adams, J. B. (1982). Microcolonial fungi-common inhabitants on desert rocks. Science 215, 1093-1095. doi: 10.1126/science.215.4536.1093

Stanier, R. Y., Kunisawa, R., Mandel, M., and Cohen-Bazire, G. (1971). Purification and properties of unicellular blue-green algae (order Cchroococcales). Bacteriol. Rev. 35, 171.

Sterflinger, K. (1998). Temperature and NaCl- tolerance of rock-inhabiting meristematic fungi. Anton. Van Leeuwenhoek Int. J. Gen. Mol. Microbiol. 74, 271-281. doi: 10.1023/A:1001753131034

Sterflinger, K. (2000). Fungi as geologic agents. Geomicrobiol. J. 17, 97-124. doi: $10.1080 / 01490450050023791$

Takahashi, F., and Shimaoka, T. (2012). The weathering of municipal solid waste incineration bottom ash evaluated by some weathering indices for natural rock. Waste Manag. 32, 2294-2305. doi: 10.1016/j.wasman.2012.06.009

Tamaru, Y., Takani, Y., Yoshida, T., and Sakamoto, T. (2005). Crucial role of extracellular polysaccharides in desiccation and freezing tolerance in the terrestrial cyanobacterium Nostoc commune. Appl. Environ. Microbiol. 71, 7327-7333. doi: 10.1128/AEM.71.11.7327-7333.2005

Tashpulatov, Z., Baibaev, B. G., and Shul'man, T. S. (2000). Chemical composition of mycelium of the thermotolerant fungus penicillium atrovenetum. Chem. Nat. Comp. 36, 518-520. doi: 10.1023/A:1002851826381

Taylor, L. L., Leake, J. R., Quirk, J., Hardy, K., Banwart, S. A., and Beerling, D. J. (2009). Biological weathering and the long-term carbon cycle: integrating mycorrhizal evolution and function into the current paradigm. Geobiology 7 , 171-191. doi: 10.1111/j.1472-4669.2009.00194.x

Urzì, C., and Realini, M. (1998). Colour changes of Noto's calcareous sandstone as related to its colonisation by microorganisms. Int. Biodeter. Biodegr. 42, 45-54. doi: 10.1016/S0964-8305(98)00045-6

Wallander, H., Johansson, L., and Pallon, J. (2002). PIXE analysis to estimate the elemental composition of ectomycorrhizal rhizomorphs grown in contact with different minerals in forest soil. FEMS Microbiol. Ecol. 39, 147-156. doi: 10.1111/j.1574-6941.2002.tb00916.x

Wallander, H., Mahmood, S., Hagerberg, D., Johansson, L., and Pallon, J. (2003). Elemental composition of ectomycorrhizal mycelia identified by PCR-RFLP analysis and grown in contact with apatite or wood ash in forest soil. FEMS Microbiol. Ecol. 44, 57-65. doi: 10.1016/s0168-6496(02)00456-7

Warscheid, T., and Braams, J. (2000). Biodeterioration of stone: a review. Int. Biodeter. Biodegr. 46, 343-368. doi: 10.1016/S0964-8305(00)00109-8

Weber, B., Scherr, C., Bicker, F., Friedl, T., and Büdel, B. (2011). Respirationinduced weathering patterns of two endolithically growing lichens. Geobiology 9, 34-43. doi: 10.1111/j.1472-4669.2010.00256.x

White, A. F. (2008). "Quantitative approaches to characterizing natural chemical weathering rates," in Kinetics of Water-Rock Interaction, eds S. L. Brantley, J. D. Kubicki, and A. F. White (New York, NY: Springer), 469-543.

Conflict of Interest Statement: The authors declare that the research was conducted in the absence of any commercial or financial relationships that could be construed as a potential conflict of interest.

Copyright (C) 2016 Seiffert, Bandow, Kalbe, Milke and Gorbushina. This is an openaccess article distributed under the terms of the Creative Commons Attribution License (CC BY). The use, distribution or reproduction in other forums is permitted, provided the original author(s) or licensor are credited and that the original publication in this journal is cited, in accordance with accepted academic practice. No use, distribution or reproduction is permitted which does not comply with these terms. 